\title{
Using Terrestrial Laser Scanning for the Recognition and Promotion of High-Alpine Geomorphosites
}

\author{
L. Ravanel $\cdot$ X. Bodin $\cdot$ P. Deline
}

Received: 30 September 2012 / Accepted: 28 February 2014 / Published online: 13 March 2014

(C) The European Association for Conservation of the Geological Heritage 2014

\begin{abstract}
High-alpine geomorphosites are poorly understood and developed, mostly because of the heavy constraints of high mountain areas. Meanwhile, they are geoheritage areas that are often extremely vulnerable to global warming: glaciers and permafrost areas are currently affected by major changes due to increasing air temperature. To deal with the high spatial variability of landforms and processes, research on alpine geomorphosites often needs the use of advanced methods of high-resolution topography, among which terrestrial laser scanning plays an increasingly crucial role. Carried out on some tenth of high-elevation sites across the Alps since the beginning of the 2000s, this method is particularly interesting for the recognition and development of high-alpine geomorphosites. Indeed, it can be implemented for identifying and characterizing the geomorphic objects (survey, monitoring and mapping), helping planning and protection policies and serving geotouristic development (communication about the processes involved, basis for documents).
\end{abstract}

Keywords High-alpine geomorphosites · Terrestrial laser scanning · Debris-covered glacier · Rock glacier · Rock wall · Geotourism

\section{Introduction}

A geomorphological geotope - a geomorphosite - refers to a landform with a particular value (scientific, cultural,

L. Ravanel $(\bowtie) \cdot$ X. Bodin $\cdot$ P. Deline

EDYTEM, University of Savoie, CNRS, 73376 Le Bourget-du-Lac,

France

e-mail: Ludovic.Ravanel@univ-savoie.fr

L. Ravanel

Institute of Geography and Durability, University of Lausanne,

Géopolis, 1015 Lausanne, Switzerland economic, etc.) due to human perception and/or exploitation (Panizza 2001). It can be a simple geomorphological object or a large portion of landscape. In high-alpine areas, despite their touristic attractiveness, very few landforms are recognized as such because of access, recognition and promotion difficulties.

The meaning of the term 'high-alpine geomorphosite' is an alternative to 'high mountain' which is not well defined. We will take here the advantage of coupling a morphoclimatic with a geometric approach. High mountain is therefore a highorder landform with a pronounced relief, composed of terrain with steep and highly variable slopes and a large relative relief. Such an environment, and especially its highest part, is often affected by the cryosphere, as cold conditions allow the presence of water in its solid state. Glaciers and permafrost, together with snow, are evidence of a specific range of glacial and periglacial processes. Generally, soils are poorly developed; vegetation is scarce and limited to discontinuous alpine meadow, lichens and mosses.

Similarly to high-latitude regions, the high mountain is very sensitive to environmental changes. Following Chardon (1984), we are tempted to place the lower limit of high mountain at the altitude of the mean annual air temperature of $0{ }^{\circ} \mathrm{C}$, i.e. at the lower limit of the periglacial-type belt. However, this limit can be lowered by several hundred metres because of the dominance effect, as glaciers have a morphogenic action sometimes well below 2,500 $\mathrm{m}$ a.s.l. or active rock glaciers export ice-rich permafrost down to 2,400 $\mathrm{m}$ a.s.1. Arbitrarily, we will place the limit of the high-alpine mountain in the European Alps at an elevation of 2,000 m a.s.l., around the upper forest limit. The fast-evolving geomorphological conditions of those areas, especially because of the global warming, can modify, damage or destroy geomorphosites, reducing or increasing their interest.

In the current context of global warming, the Alpine cryosphere is the subject of serious concerns. The air 
temperature has increased much more at high elevation especially in the Alps than elsewhere in the Northern Hemisphere. There, the mean annual air temperature has increased by more than $1.5^{\circ} \mathrm{C}$ from 1906 to 2005 , whereas it increased by $\mathrm{c}$. $0.74{ }^{\circ} \mathrm{C}$ during the same period for the whole Earth (Beniston 2005). For the end of this century in the Alps, the average temperature could increase by 4 to $5^{\circ} \mathrm{C}$, with extreme summer temperatures that can exceed the current ones by 6 to $8^{\circ} \mathrm{C}$ (Beniston 2004). In part, because this region is particularly sensitive to warming, high-alpine landforms are objects to recognize and protect, especially as they are often ignored.

Capturing the glacio-geomorphological changes that affect the high mountain cryosphere is a challenging task, as those changes can vary a lot in space and time. An accurate, robust, repeatable and flexible methodology has to be designed that must also support harsh environmental conditions without perturbing the studied object. Unlike the traditional photogrammetric methods, laser scanning directly collects dense point clouds. This method thus appears as particularly advantageous in mountain regions, especially in high mountains where rough surfaces often make topographic surveys difficult.

This paper raises the question of the interest in the terrestrial laser scanning (TLS) techniques to recognize, characterize and valorize the high-alpine geomorphosites. In the first section, we will describe the methodological framework and explain why laser scanning has probably been the most important technology introduced in topographic mapping in the last decade, providing a fast method for 3D data collection. In the second section, an overview will be given of the studies that have used TLS techniques to investigate high-alpine landforms, focusing on specific examples that emphasize the interest of diachronic TLS to quantify surface changes and processes. The third section will discuss the relevance of the TLS techniques for valorizing/developing/promoting highalpine geomorphosites.

\section{The Terrestrial Laser Scanning Method}

The topographic survey of complex surfaces like rock walls or debris accumulations poses many problems when using traditional measurement techniques (e.g. total station). Moreover, these techniques are poorly adapted to frequent and short interventions (constraints in access and weather) that are required to study the dynamics of such objects. The TLS is an innovative method in the field of topography but is still poorly used to monitor the dynamics of high mountain rock slopes (Rabatel et al. 2008) or rock glaciers (Avian et al. 2009; Bodin et al. 2008). It allows rapid survey of large areas with very high resolution and accuracy and provides high-quality $3 \mathrm{D}$ models, of which diachronic comparison allows the measurement of morphological changes (Abellan et al. 2006; Oppikofer et al. 2008).

\section{Theoretical Framework}

Terrestrial laser scanning is a light detection and ranging (LiDAR) technology dating back nearly 30 years. It is based on the transmission-reception of infrared light signals with very low spatial dispersion and high temporal precision (Fig. 1). The 'time of flight' of the laser beam allows measuring distances of several hundred metres with centimetre accuracy (Slob and Hack 2004).

Recently, new directions for LiDAR technology have emerged, thanks to both higher computing capacities and the increasing precision of available devices. Laser scanners combine the specificities of the laser (directional nature of the rays) and radar (location). Moreover, it is possible to generate pulses of very short duration, which allows scanners to transmit and receive several thousand pulses per second through the combination of a powerful laser transmitter, a highperformance opto-mechanical reflector and a receiver. Therefore, the survey of large topographic surfaces is possible at relatively low time/money cost. For further reference on TLS basic principles, see Heritage and Large (2009) and Shan and Toth (2009).

In the field of geomorphology, TLS can be conducted with several purposes: mapping, geometry and monitoring (Jaboyedoff et al. 2012). Regarding the latter, many studies were conducted on a wide range of geomorphological objects, but very few in high mountains (Avian et al. 2009; Oppikofer et al. 2008; Rabatel et al. 2008; Bodin et al. 2008; Ravanel et al. 2011). TLS appears to be a promising technology despite its limitations (weight of equipment, cost of scanners and processing software and high processing time in particular).

\section{Data Acquisition and Post-Processing}

Since the improvement of the first terrestrial laser scanner in 1999 , laser scanners have been continuously in progress. The development of sensors designed to quickly collect 3D data has enabled high-density measurements to be made across landscapes that are not otherwise suited for traditional techniques due to their inaccessibility, hazardous nature or spatial extent (Heritage and Large 2009). The rate of data acquisition is a major advantage: the first long-range device (Leica Cyrax 2400) collected 100 points per second; today, it is approximately 100 times that amount for the Optech Ilris LR, 500 times for the Leica ScanStation C10 and 2,200 times for the Riegl VZ-6000 which can acquire data up to $6 \mathrm{~km}$. The wavelength ranges between 500 and $1,700 \mathrm{~nm}$, the TLS range increasing with longer wavelengths (Jaboyedoff et al. 2009). Accuracy is typically a few millimetres at $100 \mathrm{~m}$. There are currently a dozen long-range scanners on the market; together 
Fig. 1 Basic operation of a laser scanner using the time of flight (TOF) method, and positioning of a point in the scanner own system

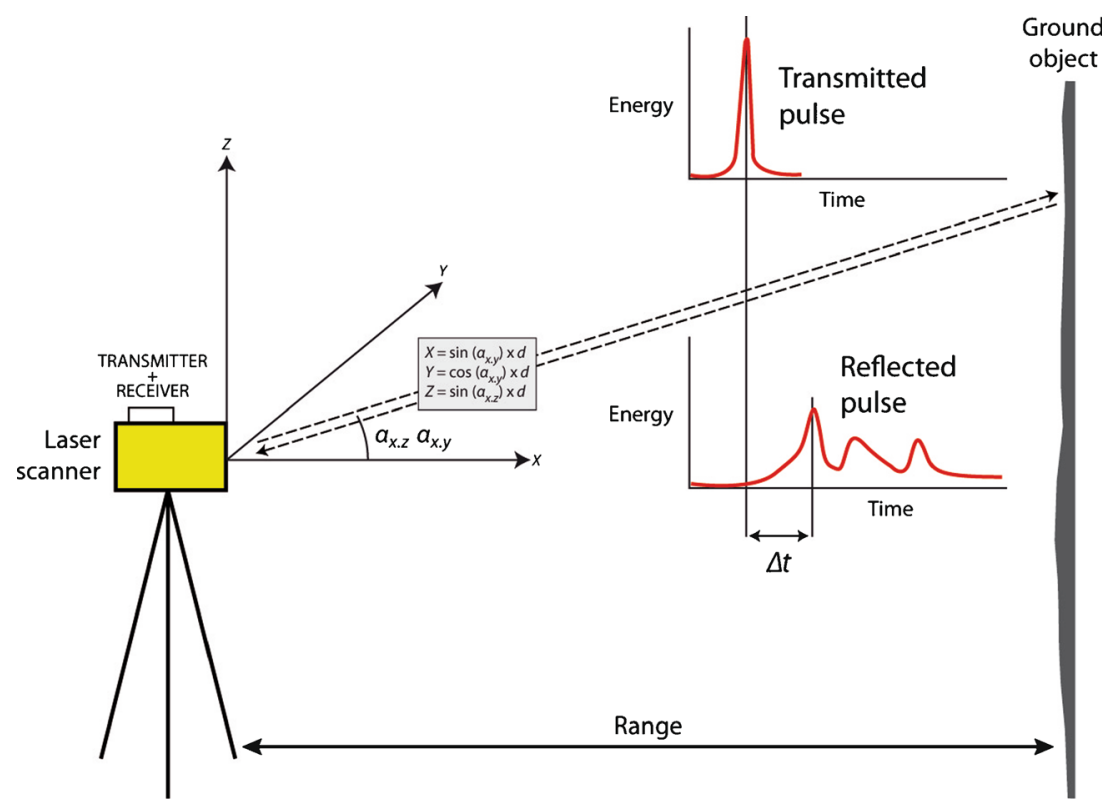

with Leica, Trimble, I-Site, Measurements Devices Ltd and Topcon, the major brands are mentioned above.

In addition to the position, the intensity of the reflected signal is acquired. This parameter mainly depends on the beam wavelength, type of material, soil moisture and angle of incidence (Jaboyedoff et al. 2012). Some limits of the TLS should not be ignored: the weight (usually around $50 \mathrm{~kg}$ for the device, its supporting structure and batteries) the high cost (purchase and maintenance), the relative complexity and time-consuming post-processing. In high mountain areas, it can be advantageous to replace heavy batteries with small power generators.

The scanning method commonly uses measurements of a number of targets (a block or an artificial object like a sphere) recognizable on the point clouds, which allow multiple scans to be geometrically related to each other. The scanner is mounted on a fixed and stable station (e.g. a tripod) and placed at one location in the survey site. Measurements are taken in a number of targets/recognizable points as well as in the actual object of interest. Initialization and configuration of the scanners are controlled with a field computer. After determining the shooting windows (usually on a photo taken beforehand) and the point spacing, the acquisition is carried out automatically. When a scan is made, the data points are given with Cartesian coordinate measurements relative to the location of the scanner itself. The scanner is then moved to a second location and the process repeated, using at least three common points on the scanned object from the first scanner location. A maximum coverage of the site is sought, sometimes limited by the terrain/laser angle and the topography of the place that may generate sheltered areas not reachable by the laser beam. When no targets are available, a $30 \%$ overlap between each point cloud (or 3D image) is needed to enable the registration of the 3D models.
The processing of the raw output from a scan or set of scans is demanding in terms of computing resources, as hundreds or even thousands of millions of measurement points are commonly acquired. The data processing of these very large 3D data sets is therefore a time-consuming and labour-intensive task, performed with dedicated software (e.g. Polyworks by InnovMetric, 3DReshaper by Technodigit), in order to obtain high-resolution 3D models.

The registration of a complete TLS data set includes an initial stage of assembling scenes (shot from different stations) together; thanks to the manual recognition of ' $n$ pairs of corresponding points'. This is then usually improved using a 'best fit' tool (working with the least squares method) with an iterative algorithm (Eggert et al. 1998) based on the iterative closest point method (ICP; Besl and McKay 1992), minimizing the distance between overlapping scenes (controlled with a convergence criterion).

Scans are first registered within the local coordinate reference system (CRS) of the first scan, but georeferencing into a specific CRS is also possible using targets accurately positioned, e.g. with differential GPS.

The registered and georeferenced output products of TLS commonly available for high mountain studies are (a) point clouds, (b) digital elevation models (DEM) and (c) triangular irregular network (TIN) models, i.e. polygonal models. Subsequent products can easily be derived from the latter: structural measurements, geometric entities, cross sections, topographic measurements, etc.

\section{Diachronic 3D Model Comparison}

TLS is increasingly used for the monitoring (diachronic comparisons) of the dynamics of natural objects, mainly in order to 
derive high-resolution volumetric and/or kinematic changes that can be then interpreted in terms of processes (Ravanel et al. 2013). Three main ways to perform such comparisons are available that can be distinguished according to the type of software employed to carry out the analysis:

1. Measurement of distances and volumes on the 3D object itself (point cloud or polygonal/TIN model) within point cloud dedicated software (e.g. InnovMetric). The differences between them, i.e. the distances between points of the 'data' and the nearest points of the 'reference', are computed either along the shortest distance between the two models or along a predefined axis (Adams and Chandler 2002; Young and Ashford 2006; Heritage and Large 2009; Ravanel et al. 2010). This volumetric information can be completed with distance manually measured on well-identifiable targets (like blocks) to assess surface movement.

2. Measurement of vertical changes by computing the DEM's difference, either on an areal basis or along cross sections, mostly performed within GIS. Either maps or vertical profiles are extracted, which can also be easily compared with other georeferenced data sets.

3. Determination of surface changes through pattern recognition methods, such as image correlation analysis. This type of approach allows for automatically determining the displacement of individual points or objects between two data sets.

\section{Use of the Terrestrial Laser Scanning on High-Alpine Landforms}

According to our inventory of studies and work in progress using TLS, the method was/is used on 40 sites (not all geomorphosites) throughout the Alps, mainly in Austria, France and Switzerland (Fig. 2). These sites contain the major landforms of the periglacial, glacial and supraglacial belts in the Alps (Fig. 3): debris-covered glaciers, surficial deposits (rock glaciers, screes and moraines), and rock walls - clean (debris-free) glacier study with TLS was until recently limited by the absorption of the laser signal by ice. Such landforms, beside their aesthetical value for most people that visit high mountain areas, are evidence of specific processes and indicate the present (or past) state of climate and/or glaciogeomorphic systems.

\section{Debris-Covered Glaciers}

Debris-covered glaciers are glaciers with a wide continuous surficial layer of debris over the ablation zone, generally indicative of a negative mass balance and related to rockfalls from surrounding rock walls.

Only a few debris-covered glaciers are surveyed by TLS, presumably because of the lack of scientific questions specifically requiring this type of method. Moreover, it is often difficult to have a bird's eye view on such objects whose main dimension is generally sub-horizontal, i.e. not conducive to TLS. Very few TLS studies have thus been conducted, but the presence of insulating debris deposited upon a glacier profoundly modifies its hydrology and dynamics, two elements still poorly characterized and understood in these contexts (Kellerer-Pirklbauer et al. 2008; Deline 2009). Two debriscovered glaciers have been surveyed with TLS since the early 2000s in Austria: Pasterze Glacier (Avian and Bauer 2006), the largest glacier in the Eastern Alps, and Goessnitzkees (Bauer et al. 2006), both in the Hohe Tauern massif. Repeated surveys allow a full description of temporal changes in volume and morphological shape to be derived.

More recently, similar studies started in the Mont Blanc massif: on the Mer de Glace (France) and on the front area of the Brenva Glacier and at the ice-marginal Miage Lake (Conforti et al. 2005) on the Italian side of the massif. In this latter case, 14 TLS surveys have been carried out on this site from July 2003 to October 2011 to study the dynamics of the ice/lake system reflected by the evolution of the ice cliff bounding the lake in relation to the 2004 drainage of the lake (Deline et al. 2011).

\section{Superficial Deposits}

Two types of landform in high mountain surficial deposits have been studied so far: moraines, which are deposits related to glacier motion and erosional activity, and rock glaciers, which relate to the steady creep of Alpine permafrost (Haeberli et al. 2006).

The Gentianes Moraine (2,894 m a.s.l., Valais, Switzerland) is the only moraine that has been the subject of a detailed TLS study in the Alps. Because of its significant anthropogenic component making it vulnerable to instabilities that regularly affect its inner flank, the Gentianes Moraine appears to be a particularly conducive site to study glacierpermafrost relationships. The comparison of eight 3D models acquired between 2007 and 2011 indicates a very high morphogenic activity of the moraine including seven landslides with a volume ranging between 111 and $1,138 \mathrm{~m}^{3}$ and which result from the combined role of the glacier retreat and, to a lesser extent, the degradation of permafrost.

Regarding rock glaciers, several alpine sites have been/are still surveyed with TLS. On the very active Hinteres Langtalkar rock glacier, in the Hohe Tauern (Austria), Bauer et al. (2003) and Avian et al. (2009) point to highly variable surface changes: the upper part of the rock glacier is probably experiencing a decrease of the debris supply whereas the front 
Fig. 2 High-alpine $(>2,000 \mathrm{~m}$ a.s.1.) study sites where TLS is used

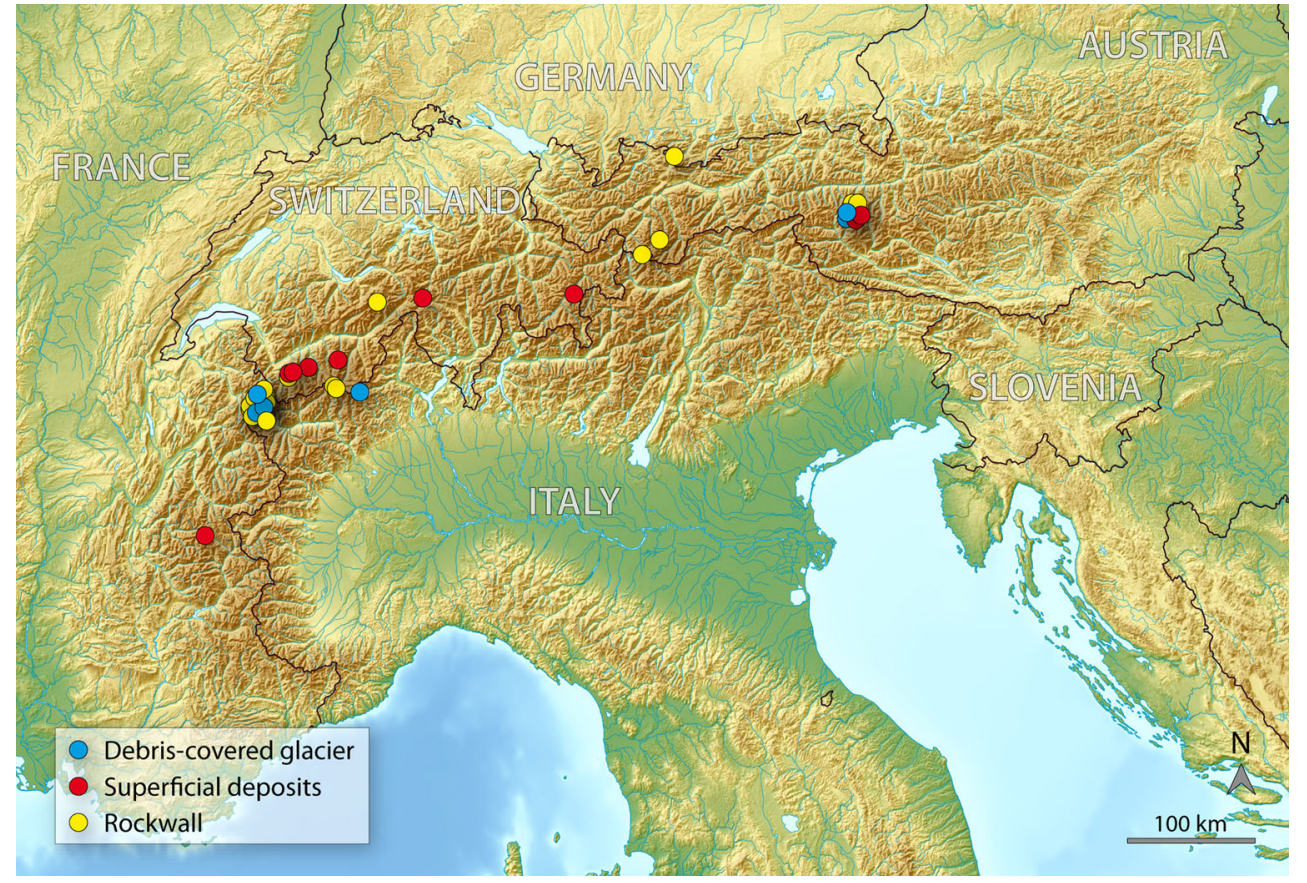

is characterized by extensive mass wasting and partial disintegration. More recently, the Glatzbach catchment (Hohe Tauern) has been the subject of attention: TLS and

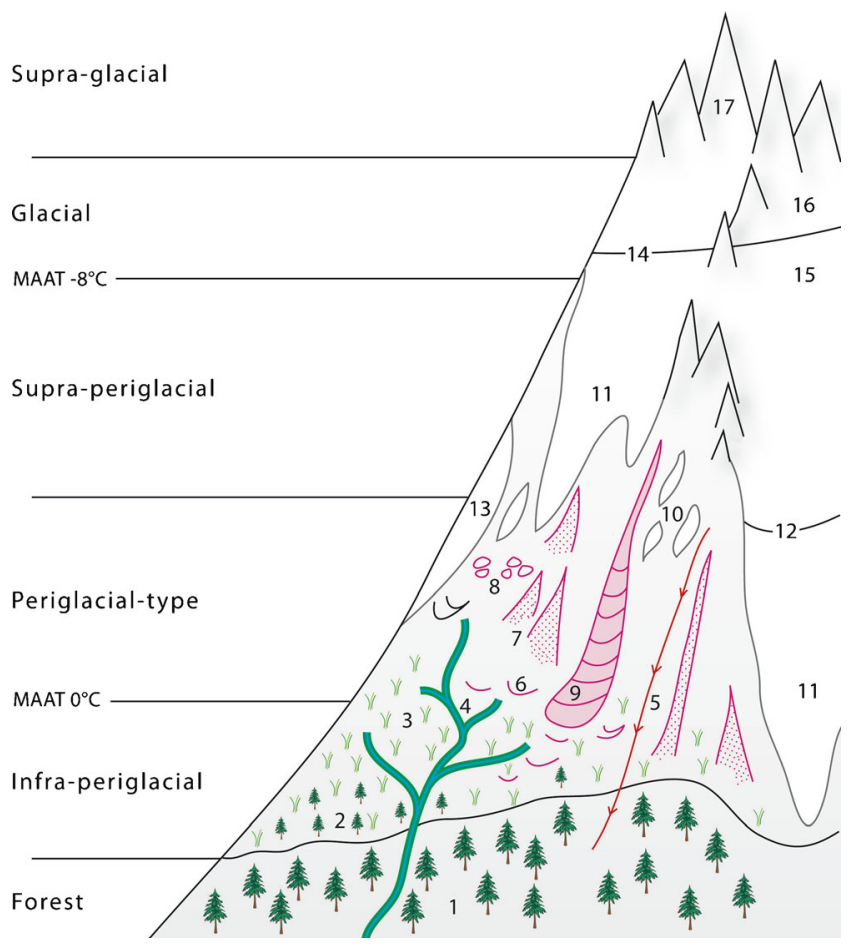

Fig. 3 Morphodynamic altitudinal belts of the high mountain in the Western Alps (Chardon 1984, modified). 1 forest, 2 Kampferzone, 3 Alpine meadow, 4 gullies, 5 avalanche couloir, 6 periglacial solifluction lobe, 7 frost-shattered scree, 8 patterned ground, 9 rock glacier, 10 firn, 11 glaciers, 12 snowline, 13 residual glacier, 14 limit 15/16, 15 warm-based glacier, 16 cold-based glacier, 17 supraglacial peaks and rock walls. MAAT mean annual air temperature geophysical data were combined in order to understand the control of surface characteristics on permafrost distribution (Otto et al. 2012).

At the Laurichard rock glacier (Combeynot massif, France), surveyed since 1979 with a total station (Francou and Reynaud 1992; Bodin et al. 2009), TLS was performed in September 2005, October 2006 and September 2011. Various strategies, including 3D point cloud processing and image correlation tools, were employed to (a) adjust separately annual scenes, (b) reference them in a common geodetic framework, (c) compare them together with a sub-decimetric precision, and (d) extract various spatially distributed measurements of the rock glacier surface deformation. The image correlation approach is especially promising (Deroux 2012) for quantifying vertical and horizontal displacements of the surface with high precision and resolution. This type of approach has also been implemented in Switzerland on the rock glaciers of Tsarmine, Perroc, Attelas, Lac des Vaux (Valais) and on the rock glacier of Foura da l'amd Ursina (Engadine).

\section{Rock walls}

It is probably for very steep natural objects that the TLS is the most suited and relevant. Survey of complex topographic surfaces as rock faces poses indeed many problems in planimetry and altimetry when using traditional measurement techniques. In addition, these techniques are poorly suited to frequent interventions and to a fieldwork duration that should be as short as possible due to risks, access constraints and fast weather evolution. Bauer et al. (2005) were the first to emphasize the potential of the method for automatically detecting 
changes and motion on the surface of an active area in terms of rockfall.

Probably the first surveys at high elevation, TLS surveys have been carried out since 2005 in the Mont Blanc massif in order to quantify the rate and intensity of rockfall in permafrost-affected rock walls (Rabatel et al. 2008; Ravanel et al. 2011). Seven rock walls were selected to be representative of the topographic and geological contexts of the massif and are since then scanned once or twice a year, including the Aiguille du Midi (3,842 m a.s.1.), a peak with heavy touristic infrastructure (Deline et al. 2009) and the very active west face of the Drus which experienced a rockfall of $265,000 \mathrm{~m}^{3}$ in 2005 (Ravanel and Deline 2008). In total, 59 rock detachments with volumes ranging from 1 to $426 \mathrm{~m}^{3}$ were recorded by TLS data set comparison between 2005 and 2009 .

The frequency and intensity of these instabilities vary considerably from one wall to another, from high-altitude areas probably characterized by a cold permafrost which stabilize the rock walls to the east face of the Tour Ronde whose active morphodynamics (Rabatel et al. 2008; Fig. 4) probably results from the combination of high density of fractures, ice/snow cover in decline and permafrost degradation (Ravanel et al. 2010, 2011).

Other TLS studies have been conducted across the Alps:

- On the Zugspitze, Germany's highest peak.

- In Switzerland, Oppikofer et al. (2008) record and quantify the relative motion of the various elements of a large landslide $\left(2 \mathrm{M} \mathrm{m}^{3}\right)$ that occurred in the Bernese Oberland in Summer 2006. Kenner et al. (2011) monitored a recently deglaciated permafrost-affected rock wall at Gemsstock in the central Swiss Alps, detecting mass movements of around $1,800 \mathrm{~m}^{3}$ over a period of 4 years.

- In Italy, several surveys in 2007 were carried out in the area of the Carrel Hut at the Matterhorn (Martelli et al. 2008). Viero et al. (2012) have conducted a back analysis of the Cima Una (Val Fiscalina, Dolomites) of 2007 where $40,000 \mathrm{~m}^{3}$ of rock collapsed.

- Finally, two recent studies focused on the stability of rock faces in Austria: TLS has been used to get more detailed information about the geometry and the temporal deformation behaviour (Fey et al. 2012), while Hartmeyer et al. (2012) started a new long-term monitoring for mass movement and permafrost interaction at the Kitzsteinhorn (Hohe Tauern).

\section{Relevance of TLS for the High-Alpine Geomorphosites}

A geomorphosite can be defined as a geomorphic object or site with an interesting value for the understanding of the history of the Earth (Grandgirard 1997). Such sites demonstrate past climates, environments or geographies or allow the observation of past or current processes (Reynard 2009). This definition suggests that the value of a geomorphic object depends strictly on its contribution to the improvement of scientific knowledge (Maillard and Reynard 2011). The quality of an object is defined on the basis of a number of evaluation criteria, the most important being its representativeness, integrity, rarity and paleogeographic importance (Reynard 2009).
Fig. 4 Comparison of the 3D models of July 2005 and September 2009 of the east face of the Tour Ronde and location of the 19 identified rockfalls ( 1 to $224 \mathrm{~m}^{3}$ ) between the two dates

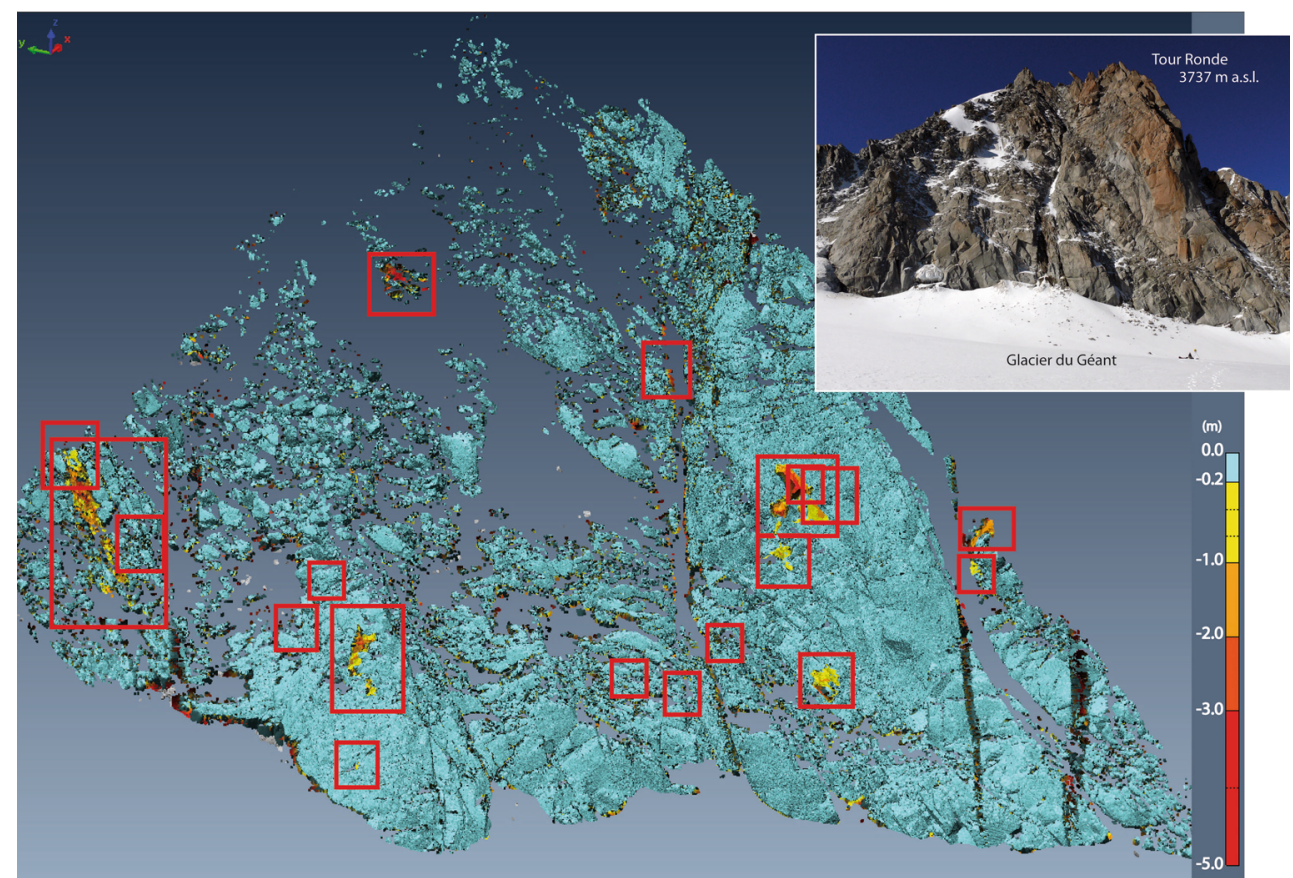


Other researchers have a broader view of the concept, assigning a cultural dimension (Panizza and Piacente 1993). In this way, geomorphosites can also be judged on their aesthetic quality, their cultural assets and their economic interest. These values make geomorphosites worthy to be preserved and passed on, as geoheritage places, to future generations (Regolini 2012). To balance the importance of the different values assigned to a site, Reynard (2005) proposed to distinguish the central scientific value and other values, which are called 'additional'. Once these values are quantified, a site recognized as a geomorphosite can be protected and developed. We will study here what the TLS method can bring to the triptych recognition/protection/development.

\section{Identifying and Characterizing the Objects of Interest}

Research on geomorphosites often focuses on the development of assessment procedures (Grandgirard 1997, 1999), and many inventories of geomorphosites have emerged. According to its definition, a geomorphosite has tangible (landforms and geomorphic processes) and intangible components (values assigned to various geomorphic processes or landforms) (Regolini 2012), which can be assessed.

From a physical point of view, geomorphosites are landforms shaping the Earth's surface. They are classified as active, when processes are underway, and as passive, when processes leading to their formation stopped. Generally, landforms that are TLS surveyed are thought to be active. Scientific issues determining sites that should be topographically modelled are focused on processes in action, mostly glacial (e.g. glacial melting under debris cover, evolution of ice cliff) and periglacial processes (e.g. rock glacier deformation, rockfall) in high mountains. When TLS is not carried out for a monitoring purpose, scientific issues focused on processes are still present. At the top of the Aiguille du Midi, at the Glatzbach catchment or at the Aiguille de Tré-la-Tête, a TLS survey was for example carried out in order to obtain 3D models, materials for geophysical methods or structural analysis. In addition, a few sites have been scanned only once (e.g. Tsarmine or Perroc rock glaciers) in order to obtain a topographic state at $t_{0}$, useful if a process then reshapes the site.

In the realm of geoheritage recognition and promotion, TLS constitutes a very precious component of study, which is one of the bases of scientific reasoning in geomorphology, often followed by mapping. In the characterization of the tangible component of a landform, TLS indeed provides the finest (in a spatial resolution sense) possible information on its spatial settings and gives access to various embedded scales of interpretation. For example, the 2005 model of the Laurichard rock glacier allowed us to draw a morphological map on which not only the landform's boundaries are precisely delineated but also the different sub-units that compose it (Fig. 5) and the micro-morphology ('roughness') of its surface. The possibility of visualizing the geomorphic object in $3 \mathrm{D}$ greatly improves for the scientist the inspection capabilities. The recognition of the structural settings (e.g. geometry and distribution of fractures) of a sub-vertical, inaccessible rock wall is another example of the contribution of TLS to geomorphology and geomorphosite studies.

One can also emphasize the meaningful insights that could result from the possibility that virtually anyone interested in a geomorphosite can 'manipulate' the object in 3D. The appropriation of the scientific knowledge is facilitated by this means.

What is qualified as intangible refers to scientific and additional values of a geomorphosite. The fundamental difference between the two values is that the scientific value cannot be null-otherwise the site would not be considered as a geomorphosite - whereas, according to Reynard (2009), one or all the components of the additional value may be absent. Since a scientific issue predates any TLS measurements, all sites where TLS is carried out could therefore be considered as geomorphosites. Nevertheless, we feel that all sites are not necessarily geomorphosites, especially in high mountain areas where access and development conditions differ from the valley floors. Regarding scientific values, we follow Reynard (2009) who mentions for example the importance of the scarcity. However, in the Mont Blanc massif, rock walls surveyed with the TLS were generally selected on the base of their representativeness. Therefore, they are not 'rare' even if their activity may make them particularly relevant for the monitoring of slope dynamics related to permafrost degradation. In this way, the Aiguilles Marbrées, the Grand Flambeau, the Aiguilles d'Entrèves and the Androsace are not real geomorphosites especially as their cultural dimension in the sense of Panizza and Piacente (1993) is very small. 'Somewhat rare' sites can on the contrary become true geomorphosites if processes are particularly active. This is the case, for example, for the Tour Ronde which, with no real additional value, can be a geomorphosite because of its high rockfall activity (Fig. 4) probably resulting from a combination of high-density fractures, ice/snow cover in decline and permafrost degradation (Ravanel et al. 2010).

Recognition of most of the additional values derives from the links between a geomorphological site and society. These can be cultural, socio-economic or aesthetic. Because of these links, additional values of some geomorphosites may make them exceptional. This is the case, for example, of the west face of the Drus which, in addition to its great scientific value (Ravanel and Deline 2008), is an emblem of the Chamonix valley (aesthetic value), a mythical wall for climbers (cultural asset) and a foundation of the landscape of the Montenvers tourist site (economic interest). It is the same situation at the Aiguille du Midi, summit of historical interest, accessible by cable car since 1955 and visited by more than half a million people each year. It should be noted that the values assigned to 
Fig. 5 Simplified geomorphological map of the Laurichard rock glacier proposed for promotion in the Parc National des Ecrins. Horizontal

displacement fields between 2006 and 2011 are represented, derived from correlation analysis of highresolution LiDAR-derived digital elevation models (Deroux 2012)

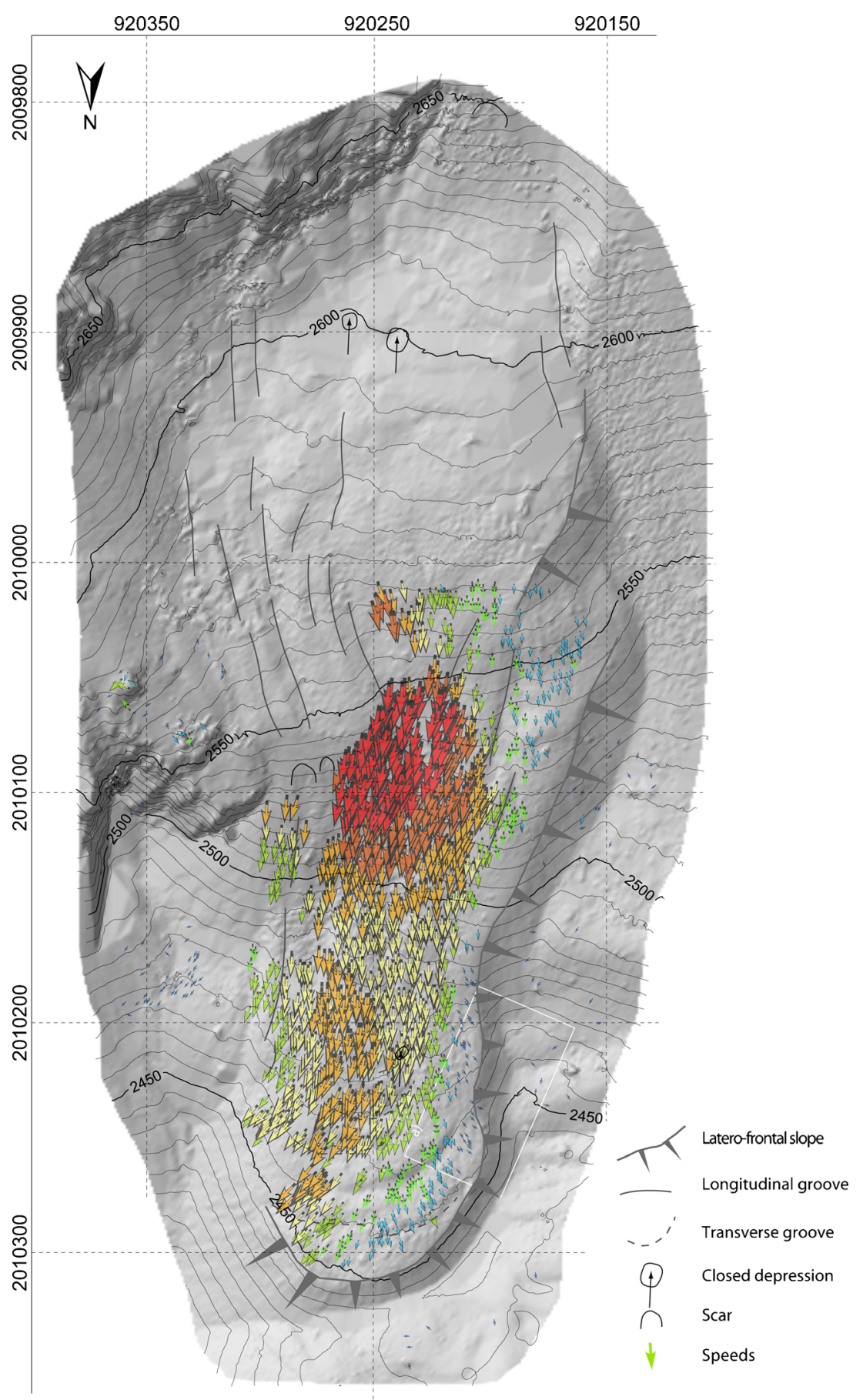

geomorphosites depend on value systems that can vary considerably according to people and societies, and may change over time (Regolini 2012).

\section{Planning Policies and Protection}

The morphodynamics of active sites can pose difficulties for the management of geomorphosites. Processes that affect them can indeed destroy the sites (concept of vulnerability) and/or pose a threat to human activity and infrastructures.
Geomorphosite vulnerability affects both their tangible and intangible components (Regolini 2012). In its tangible form, the vulnerability is expressed by the modification of a site. The origin of this change can be natural or anthropogenic. If it is natural, alteration or destruction of a site can be due to the process that created the site (destruction) or to other processes that can operate (e.g. erosion). Other exogenous factors such as climate can also play a major role (Reynard 2009). High mountain geomorphosites are particularly vulnerable because of the presence of ice in a variable amount, from glaciers to 
rock walls in which fractures can be ice filled in the context of permafrost. In the recent years, several researchers studied the sensitivity of geomorphosites to climate change or exposed to natural hazards (Alcantara-Ayala 2009; Smith et al. 2009; Diolaiuti and Smiraglia 2010; Garavaglia et al. 2010). For example, in the case of the dynamics of rock glaciers, the increasing surface velocity that is measured leads to a higher vulnerability of the landforms as they are flowing down at faster rates, thus reaching areas where climatic conditions become more and more unfavourable to their maintenance. The detailed study of the processes and factors influencing the spatial and temporal evolution of a site allowed by TLS is therefore often relevant to improve the management of a dynamic site.

The consequences of the shrinkage of mountain glaciers and permafrost degradation on the natural and cultural heritage have not yet been studied in detail; only preliminary studies have been conducted to date (e.g. Haeberli 2008). As the Mer de Glace, the largest French glacier, is becoming extensively debris-covered, the aesthetic value of the Montenvers tourist site visited by around 800,000 people each year is altered. It is the same at the Pasterze Glacier, the largest Austrian glacier that can be reached via the Grossglockner High Alpine Road and a funicular railway. In such context, the TLS method helps to identify and quantify the evolution of the glaciated areas and possibly leads to the production of landscape evolution models. These models can be used by local authorities and tourism infrastructure managers afterwards to determine patterns of development/adaptation. The shrinkage of glaciers raises questions about the maintenance of summer tourism activities in these areas with important consequences from an economic point of view. Managers of glacial geomorphosites must thus integrate climate change issues into their management plans. It is particularly important to anticipate a possible reduction in frequency with a better development of the glacial sites and their proglacial areas (cf. III3) as geomorphosites (Diolaiuti and Smiraglia 2010), especially in their historic (glacial retreat) and geomorphic (proglacial and paraglacial dynamics) dimensions.

Among geomorphosites that are monitored by TLS, rapid change of some of them - possibly seen as destruction - can enhance their scientific value. This is often the case with areas affected by permafrost degradation: without its strong recent activity measured by TLS, the Gentianes Moraine would certainly not have been perceived as a geomorphosite but rather as a 'classical' moraine hosting cable car stations without further interest besides. This scientific value can also be enhanced by the installation of additional measuring devices, following TLS measurements.

The concept of vulnerability is also an intangible expression (Regolini 2012). It stems from the concept that a heritage must be passed to future generations. This implies the preservation of this heritage in a more or less close state to the current one (geoconservation) by preventing or limiting its natural evolution by management or protection measures.

\section{Geotouristic Development}

Whether it is related to geoconservation or geotourism, the development of a geomorphosite involves many initiatives from stakeholders. Any development activity implies communication between specialists (scientists, mediators) and nonspecialists (authorities, general public) through personal (guided tours, conferences) or impersonal (exhibitions, brochures, maps, etc.) media (Regolini 2012). Even if TLS appears never to have been carried out in developing a geomorphosite, it can be of great service, especially in high mountain areas where accessibility to a site is the greatest constraint.

On the one hand, TLS - and in particular TLS monitoring - allows the better characterization and understanding of the site to develop. Increasing its scientific value, TLS also allows the development of a discourse about the object. In particular, TLS provides quantitative data (kinematics, destabilized rock volume, decrease of ice thickness, etc.) that are necessary for communicating about the processes, to the general public in particular. On the other hand, 3D models themselves can easily be used to help the development of a geomorphosite. They can be the basis for scientific, educational and popularization (Fig. 6) documents. 3D models can appear on brochures, exhibition panels or panels installed outdoor to help in interpreting landscape. A hiking trail on the theme of mountain geomorphology in the 4Vallées area (Valais, Switzerland) should be developed in the next few years, and a panel as proposed in Fig. 7 could include a TLS document. These 3D models can also be used in geomatic and multimedia tools. Such tools are becoming more and more frequent (Ghiraldi et al. 2010; Giardino et al. 2010). The use of new technologies is indeed growing rapidly. In the coming months, the $3 \mathrm{D}$ model of the west face of the Drus could be used for example to feed a smartphone application devoted to an 'open-air museum' in the Chamonix valley developed as part of the integrated transborder plan of the Mont Blanc massif area.

\section{Conclusions}

Terrestrial laser scanning is a technology based on the transmission-reception of infrared light signal with very low spatial dispersion and high temporal precision. It allows measuring distances of several hundred metres to a few kilometres with a very high accuracy. This remote-sensing technique is undergoing fast progress in the geosciences. The opportunity 

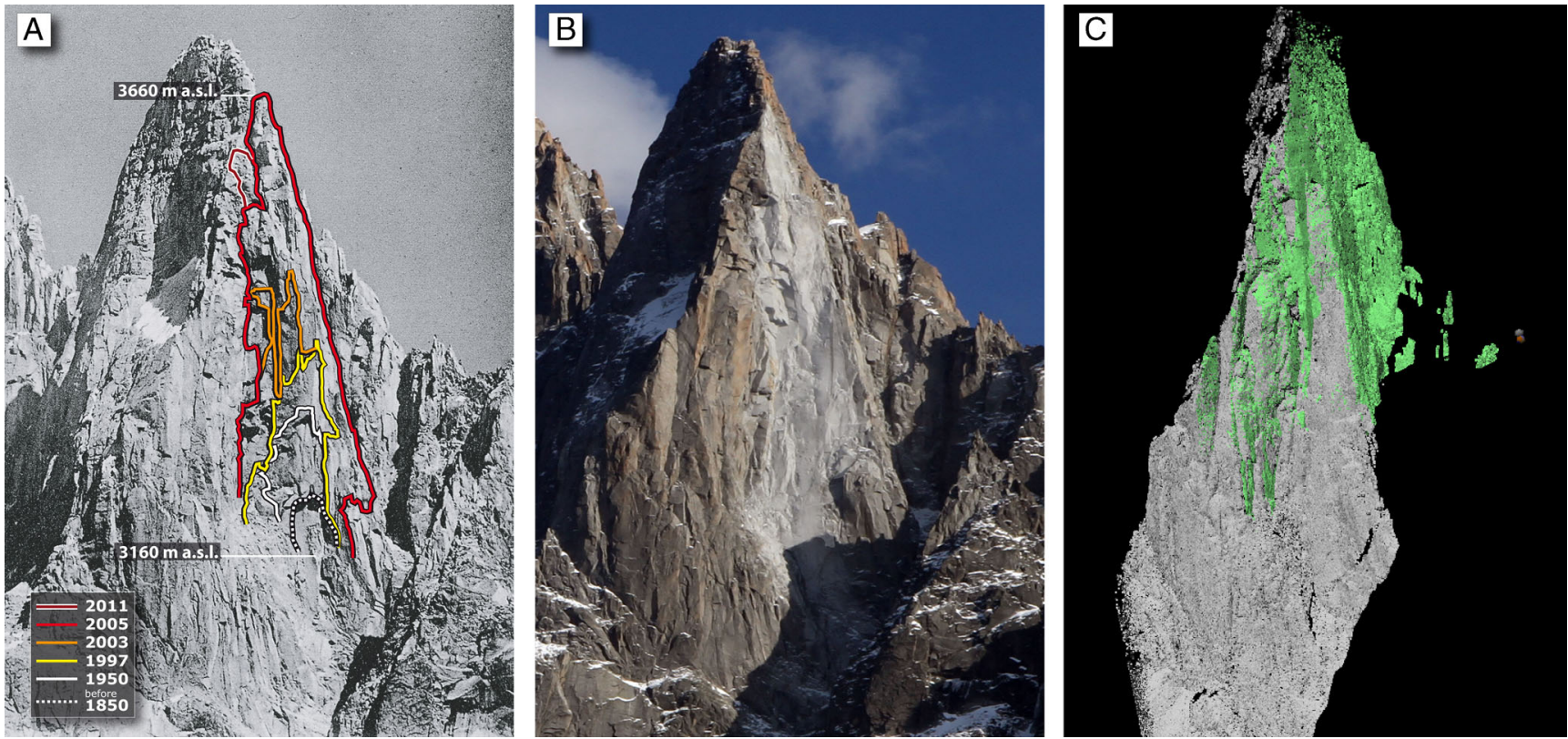

Fig. 6 The monolith of the Drus (3,730 m a.s.1.), a major geomorphosite of the Mont Blanc massif. A Reconstitution of the main rockfalls that have affected the west face since the end of the Little Ice Age ( 1855 AD), B the same face after the rockfalls of 2005 and 2011, and $\mathbf{C}$ the 3D model

of the face obtained by TLS (the grey sub-model was acquired from the foot of the rock wall, while the green one was acquired from the rock ridge that develops on the right side)

of investigating geomorphosites in high-alpine areas where such sites are still misunderstood or poorly developed.

of acquiring 3D information of natural objects with such high

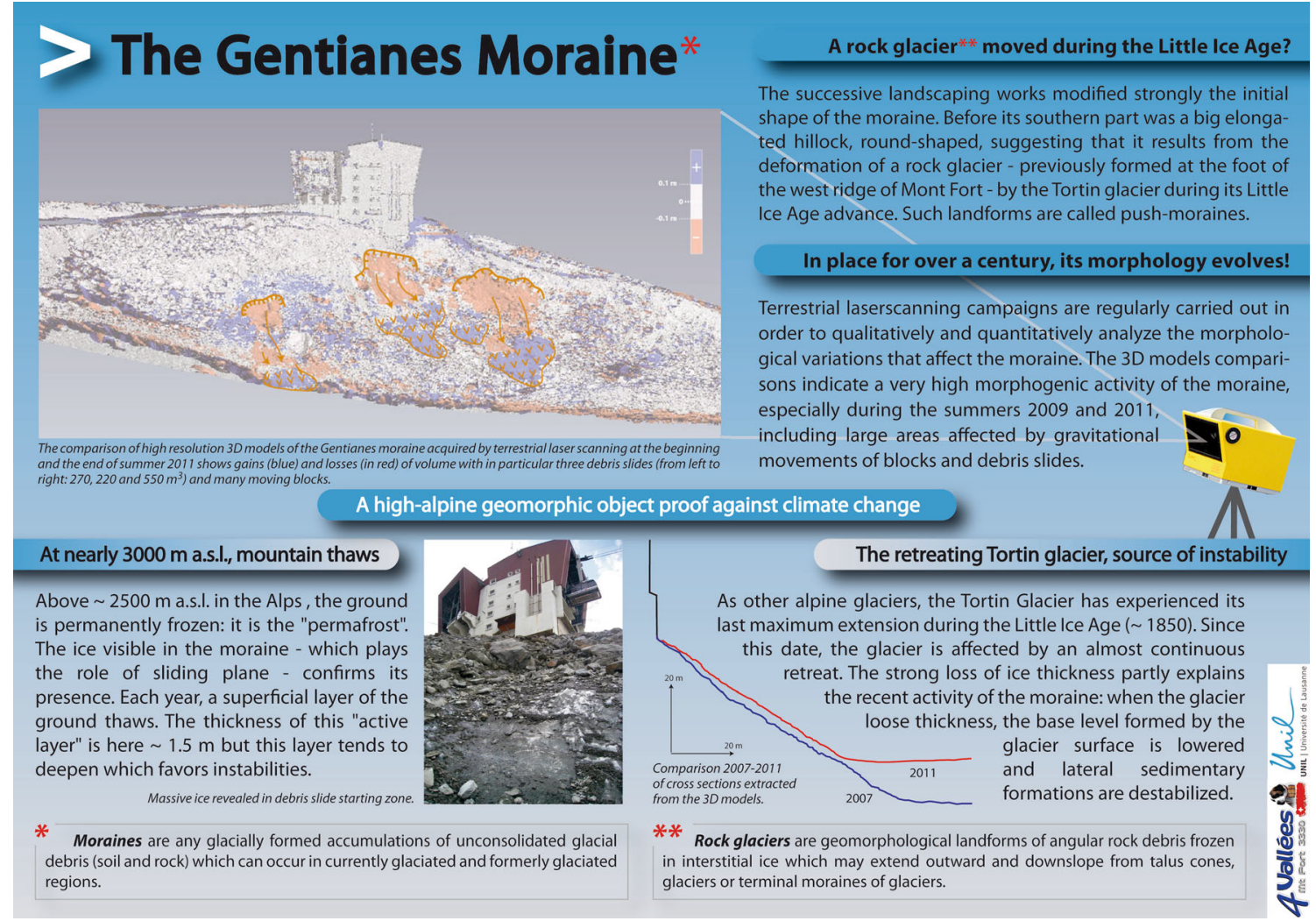

Fig. 7 Proposed information panel concerning the evolution of the Gentianes Moraine (2,894 $\mathrm{m}$ a.s.l., Valais, Switzerland) inspired by panels set up in the close area of Les Diablerets 
Until today, this method has been carried out on nearly 40 high-elevation sites across the Alps since the beginning of the 2000s, mainly on debris-covered glaciers - on which the debris layer allows the use of most current terrestrial scanners - surficial deposits and rock walls. Usually responding to questions on physical processes, this method may also be involved in different questions related to geomorphosites: identification/characterization, planning policies and protection, and geotouristic development. With global warming and associated accelerating processes, we presume that TLS will be a recognized method in the near future for evaluating and developing geomorphosites.

\section{References}

Abellan A, Vilaplana JM, Martinez J (2006) Application of a long-range terrestrial laser scanner to a detailed rockfall study at Vall de Núria (Eastern Pyrenees, Spain). Eng Geol 88:136-148

Adams JC, Chandler JH (2002) Evaluation of lidar and medium scale photogrammetry for detecting soft-cliff coastal change. Photogramm Rec 17:405-418

Alcantara-Ayala I (2009) Geomorphosites managements in areas sensitive to natural hazards. In: Reynard E, Coratza P, Regolini-Bissig G (eds) Geomorphosites. München, Pfeil Verlag, pp 163-173

Avian M, Bauer A (2006) First results on monitoring glacier dynamics with the aid of terrestrial laser scanning on Pasterze Glacier (Hohe Tauern, Austria). Grazer Schriften der Geographie und Raumforschung 41:27-36

Avian M, Kellerer-Pirklbauer A, Bauer A (2009) LiDAR for monitoring mass movements in permafrost environments at the cirque Hinteres Langtal, Austria, between 2000 and 2008. Nat Hazards Earth Syst Sci 9:1087-1094

Bauer A, Paar G, Kaufmann V (2003) Terrestrial laser scanning for rock glacier monitoring. In: Proceedings of the 8th international conference on permafrost, Zürich, pp 55-60

Bauer A, Paar G, Kaltenböck A (2005) Mass movement monitoring using terrestrial laser scanner for rock fall management. In: Proceedings of the 1st international symposium on geo-information for disaster management, Delft, The Netherlands, pp 393-406

Bauer A, Kaufmann V, Kellerer-Pirklbauer A, Avian M, Paar G (2006) Terrestrial laser scanning for glacier monitoring: a comparison to standard geodetic and photogrammetric methods, and documentation of the glacier retreat of Goessnitzkees (Schober group, Austria) between 2000 and 2005. Abstract of the 9th international symposium on high mountain remote sensing cartography, Graz, Austria, 1 $\mathrm{p}$

Beniston M (2004) The 2003 heat wave in Europe. A shape of things to come? Geophys Res Lett 31:2022-2026

Beniston M (2005) Mountain climates and climatic change: an overview of processes focusing on the European Alps. Pure Appl Geophys 162:1587-1606

Besl P, McKay N (1992) A method for registration of 3-D shapes. IEEE Trans Pattern Anal Mach Intell 14:239-256

Bodin X, Schoeneich P, Jaillet S (2008) High-resolution DEM extraction from terrestrial LiDAR topometry and surface kinematics of the creeping alpine permafrost: the Laurichard rock glacier case study (southern French Alps). In: Proceedings of the 9th international conference on permafrost, Fairbanks, Alaska, 1, pp 137-142
Bodin X, Thibert E, Fabre D (2009) Two decades of response (19862006) to climate by the Laurichard rock glacier. Permafr Periglac Process 20:331-344

Chardon M (1984) Montagne et haute montagne alpine, critères et limites morphologiques remarquables en haute montagne. Rev Géogr Alp 72:213-224

Conforti D, Deline P, Mortara G, Tamburini A (2005) Terrestrial scanning LiDAR technology applied to study the evolution of the ice-contact Miage lake (Mont Blanc, Italy). Report on the Joint ISPRS Commission VI, WG IV/4, 5 p

Deline $P(2009)$ Interactions between rock avalanches and glaciers in the Mont Blanc massif during the late Holocene. Quat Sci Rev 28: 1070-1083

Deline P, Bölhert R, Coviello V, Cremonese E, Gruber S, Krautblatter M, Jaillet S, Malet E, Morra di Cella U, Noetzli J, Pogliotti P, Rabatel A Ravanel L, Sadier B, Verleysdonk S (2009) L'Aiguille du Midi (massif du Mont Blanc): un site remarquable pour l'étude du permafrost des parois d'altitude. Collection EDYTEM 8:135-146

Deline P, Grange C, Jaillet S, Tamburini A (2011) Sept ans de suivi de la dynamique de la falaise de glace du lac du Miage (massif du Mont Blanc) par scanner laser terrestre. Collection EDYTEM 12:95-106

Deroux B (2012) Apport de la lasergrammétrie terrestre pour l'étude des déformations lentes des versants de montagne (glaciers et permafrost). Mémoire de fin d'étude, École Supérieure de Géodésie et Topographie, Le Mans, $51 \mathrm{p}$

Diolaiuti G, Smiraglia C (2010) Changing glaciers in a changing climate: how vanishing geomorphosites have been driving deep changes in mountain landscapes and environments. Géomorphologie 2:131152

Eggert DW, Fitzgibbon AW, Fisher RB (1998) Simultaneous registration of multiple range views for use in reverse engineering of CAD models. Comp Vis Im Underst 69:253-272

Fey C, Zangerl C, Haas F, Rutzinger M, Sailer R, Bremer M (2012) Rock slide deformation measurements with terrestrial laser scanning in inaccessible high mountain areas. Geophys Res Abstr 14:11944-1

Francou B, Reynaud L (1992) 10 years of surficial velocities on a Rock glacier (Laurichard, French Alps). Permafr Periglac Process 3:209213

Garavaglia V, Pelfini M, Bollati I (2010) The influence of climate change on glacier geomorphosites: the case of two Italian glaciers (Miage Glacier, Forni Glacier) investigated through dendrochronology. Géomorphologie 2:153-164

Ghiraldi L, Coaratza P, Marchetti M, Giardino M (2010) GIS and geomatics application for the evaluation and exploitation of Piemonte geomorphosites. In: Regolini-Bissig G, Reynard E (eds) Mapping geoheritage. Geovisions 35:97-113

Giardino M, Perotti L, Carletti R, Russo S (2010) Creation and test of a mobile GIS application to support field data collection and mapping activities on geomorphosites. In: Regolini-Bissig G, Reynard E (eds) Mapping geoheritage. Geovisions 35:115-127

Grandgirard V (1997) Géomorphologie, protection de la nature et gestion du paysage. Université de Fribourg, Thèse de Doctorat, $420 \mathrm{p}$

Grandgirard V (1999) L'évaluation des géotopes. Geol Insubrica 4:66-69

Haeberli W (2008) Changing view of changing glaciers. In: Orlove B, Wiegandt E, Luckman BH (eds) Darkening peaks: glacier retreat, science and society. University of California Press, Los Angeles, pp 23-32

Haeberli W, Hallet B, Arenson L, Elconin R, Humlum O, Kaab A (2006) Permafrost creep and rock glacier dynamics. Permafr Periglac Process 17:189-214

Hartmeyer I, Keuschnig M, Delleske R, Schrott L (2012) Reconstruction of the Magnetkoepfl rockfall event-detecting rock fall release zones using terrestrial laser scanning, Hohe Tauern, Austria. Geophys Res Abs 14:12488

Heritage G, Large A (2009) Laser scanning for the environmental sciences. Wiley, Chichester, 288 p 
Jaboyedoff M, Oppikofer T, Locat A, Locat J, Turmel D, Robitaille D, Demers D, Locat P (2009) Use of ground-based LIDAR for the analysis of retrogressive landslides in sensitive clay and of rotational landslides in river banks. Can Geotech J 46:1379-1390

Jaboyedoff M, Oppikofer T, Abellan A, Derron MH, Loye A, Metzger R, Pedrazzini A (2012) Use of LiDAR in landslide investigations: a review. Nat Hazards 61:5-28

Kellerer-Pirklbauer A, Lieb GK, Avian M, Gspurning J (2008) The response of partially debris-covered valley glaciers to climate change: the example of the Pasterze Glacier (Austria) in the period 1964 to 2006. Geogr Ann A 90:269-285

Kenner R, Phillips M, Danioth C, Denier C, Thee P, Zgraggen A (2011) Investigation of rock and ice loss in a recently deglaciated mountain rock wall using terrestrial laserscanning: Gemsstock, Swiss Alps. Cold Reg Sci Tech 67:157-164

Maillard B, Reynard E (2011) Inventaire des géomorphosites des vallées d'Entrement et de Ferret (Valais) et propositions de valorisations. In: Lambiel C, Reynard E, Scapozza C (eds) La géomorphologie alpine: entre patrimoine et contraintes. Geovisions 36:1-17

Martelli D, Alberto W, Tamburini A (2008) Rilievi laser scanner nell'ambito del Progetto Interreg IIIA Alcotra n. 196 PERMAdataROC. IMAGEO S.r.l., unpublished report

Oppikofer T, Jaboyedoff M, Keusen HR (2008) Collapse at the eastern Eiger flank in the Swiss Alps. Nat Geosci 1:531-535

Otto JC, Keuschnig M, Götz J, Marbach M, Schrott L (2012) Detection of mountain permafrost by combining high resolution surface and subsurface information - an example from the Glatzbach catchment, Austrian Alps. Geogr Ann A 94:43-57

Panizza M (2001) Geomorphosites: concepts, methods and example of geomorphological survey. Chin Sci Bull 46:4-6

Panizza M, Piacente S (1993) Geomorphological assets evaluation. Z Geomorphol 87:13-18

Rabatel A, Deline P, Jaillet S, Ravanel L (2008) Rock falls in high-alpine rock walls quantified by terrestrial LiDAR measurements: a case study in the Mont Blanc area. Geophys Res Lett 35, L10502

Ravanel L, Deline P (2008) La face ouest des Drus (massif du MontBlanc): évolution de l'instabilité d'une paroi rocheuse dans la haute montagne alpine depuis la fin du Petit Age Glaciaire. Géomorphologie 4:261-272

Ravanel L, Deline P, Jaillet S (2010) Quantification des éboulements/ écroulements dans les parois de la haute montagne alpine : quatre années de laserscanning terrestre dans le massif du Mont-Blanc. Rev Fr Photogram Télédétec 192:58-65

Ravanel L, Deline P, Jaillet S (2011) Quatre années de suivi de la morphodynamique des parois rocheuses du massif du Mont Blanc par laserscanning terrestre. Collection EDYTEM 12:69-76

Ravanel L, Deline P, Lambiel C, Vincent C (2013) Instability of a highly vulnerable high alpine rock ridge: the lower Arête des Cosmiques (Mont Blanc massif, France). Geogr Ann A. doi: 10.1111/geoa. 12000

Regolini G (2012) Cartographier les géomorphosites. Géovisions 38:294

Reynard E (2005) Géomorphosites et paysages. Géomorphologie 3:181188

Reynard E (2009) Geomorphosites: definitions and characteristics. In: Reynard E, Coratza P, Regolini-Bissig G (eds) Geomorphosites. München, Pfeil Verlag, pp 63-71

Shan J, Toth CK (2009) Topographic laser ranging and scanning: principles and processing. CRC Press, New York, USA, $590 \mathrm{p}$

Slob S, Hack R (2004) 3D terrestrial laser scanning as a new field measurement and monitoring technique. In: Hack R, Azzam R, Charlier R (eds) Engineering geology for infrastructure planning in Europe. A European perspective. Lecture note in Earth Sciences. Springer, Berlin / Heidelberg, pp 179-190

Smith BJ, Orford JD, Betts NL (2009) Management challenges of a dynamic geomorphosite: climate change and the Giant's Causeway Heritage Site. In: Reynard E, Coratza P, RegoliniBissig G (eds) Geomorphosites. München, Pfeil Verlag, pp 145162

Viero A, Furlanis S, Squarzoni C, Teza G, Galgaro A, Gianolla P (2012) Dynamics and mass balance of the 2007 Cima Una rockfall (Eastern Alps, Italy). Landslides. doi: 10.1007/s10346-012-0338-4

Young AP, Ashford SA (2006) Application of airbone LiDAR for seacliff volumetric change and beach-sediment budget contribution. J Coast Res 22:307-318 